\title{
濃厚赤血球の輸血による GVHD
}

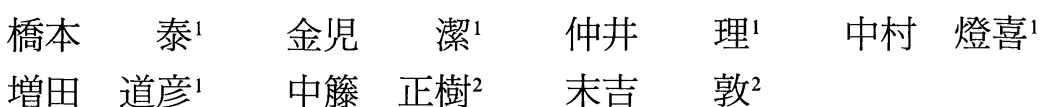

Graft versus host disease (以下 GVHD と略す) は, 輸血の合併症として比較的まれな症候群ながら, 発症すると大多数が死に至る重篤な疾患である。一 方，救急の場では，緊急に輸血する状況は決して少 なくない。当院においても，67歳女性の直腸癌の大 量下血に対して輸血し，そのため GVHD となった 症例を経験したので，これに若干の考察を加えて報 告する。

\section{症例}

患者：67 歳, 女性

主訴：下血

現病歴：1992 年 3 月 25 日, 大量の下血があり（推 定約 $1 l$ ), 緊急入院となった。直腸診にて直腸癌を疑 い，大腸内視鏡にて大腸癌取扱い規約による 2 型と 診断された。

既往歴：1992 年 1 月 6 日より 3 月 21 日まで急性 心筋梗塞の入院歴があり, 糖尿病と高血圧の基礎疾 患に加え，脳梗塞があった。

入院時現症：眼瞼結膜軽度貧血様，眼球結膜正常 で，胸部に心雑音なく，肺音も整で，腹部も理学的 所見で特記すべきことなかった。入院時の血圧は $145 / 80 \mathrm{mmHg}$, 脈拍 $90 / \mathrm{min}$, 体温 $36.9^{\circ} \mathrm{C}$ であった。 入院時検査所見としては，別表に示すように貧血が あった（Table 1)。

Graft versus host disease (GVHD) following condensed red blood cell transfusion

キーワード：GVHD，濃厚赤血球，HLA 型，直腸癌

1 宇治徳洲会病院外科 2 同内科

著者連絡先：干 611 宇治市小倉町春日森 86

原稿受理日：1993 年 12 月 13 日 (93-078)
Table 1. Clinical data on admission.

\begin{tabular}{lrlr} 
WBC & $8,100 / \mathrm{mm}^{3}$ & \multicolumn{2}{c}{ Blood type } \\
$\mathrm{Hb}$ & $8.7 \mathrm{~g} / \mathrm{dl}$ & \multicolumn{2}{c}{ O type $\mathrm{Rh}(\mathrm{D})+$} \\
$\mathrm{Ht}$ & $26.7 \%$ & GOT & $11 \mathrm{IU} / 1$ \\
$\mathrm{Plt}$ & $31.2 \times 10^{4} / \mathrm{mm}^{3}$ & GPT & $3 \mathrm{IU} / 1$ \\
& & LDH & $375 \mathrm{IU} / 1$ \\
$\mathrm{PT}$ & $100 \%$ & $\mathrm{~T} . \mathrm{Bil}$ & $0.4 \mathrm{mg} / \mathrm{dl}$ \\
$\mathrm{TT}$ & $70 \%$ & Glu & $148 \mathrm{mg} / \mathrm{dl}$ \\
& & BUN & $23.4 \mathrm{mg} / \mathrm{dl}$ \\
$\mathrm{Na}$ & $144 \mathrm{mEq} / 1$ & Cre & $1.6 \mathrm{mg} / \mathrm{dl}$ \\
$\mathrm{K}$ & $4.6 \mathrm{mEq} / 1$ & Amy & $187 \mathrm{mg} / \mathrm{dl}$ \\
$\mathrm{Cl}$ & $108 \mathrm{mEq} / 1$ & & \\
& & CEA & $4.1 \mathrm{ng} / \mathrm{ml}$ \\
\hline
\end{tabular}

入院後の経過：入院日, 大量の下血があったため, 貧血を是正するため 1 日 1 単位の condensed red blood cell（以下 CRC と略す）を連日，計 4 単位輸 血した。最初の輸血から 12 日目（第 12 病日）に高 熱あり，その翌日，全身に点状の紅斑を認めた（Fig. 1)。ついで下痢・下血を併発した。第 12 病日の血液 検査により GOT, GPT, LDH 上昇等の肝障害を認 め, 第 19 病日に汎血球減少傾向（赤血球数 $214 \times$ $10^{4} / \mathrm{mm}^{3}$, 白血球数 $3,300 / \mathrm{mm}^{3}$, 血小板数 $5 \times 10^{4} /$ $\mathrm{mm}^{3}$ ) を認め, 全身状態が不良となった。この時点で GVHD と診断した。治療として第 12 病日より偽膜 性腸炎を含めた重症感染症を考えて抗生剤 (CEZ, AZT, AMK, VCM)，第 20 病日に GVHD を考慮し てステロイドのパルス療法, granulocyte colony stimulating factor（以下 GCSF と略す）の投与と血 漿交換を行った。肝機能と血小板数の改善をみたが, 第 23 病日に多臓器不全に至り死亡した。臨床経過と して，ビリルビンの上昇は比較的軽度にもかかわら ず肝酵素の高度の上昇, 汎血球減少症, 腎不全がみ 


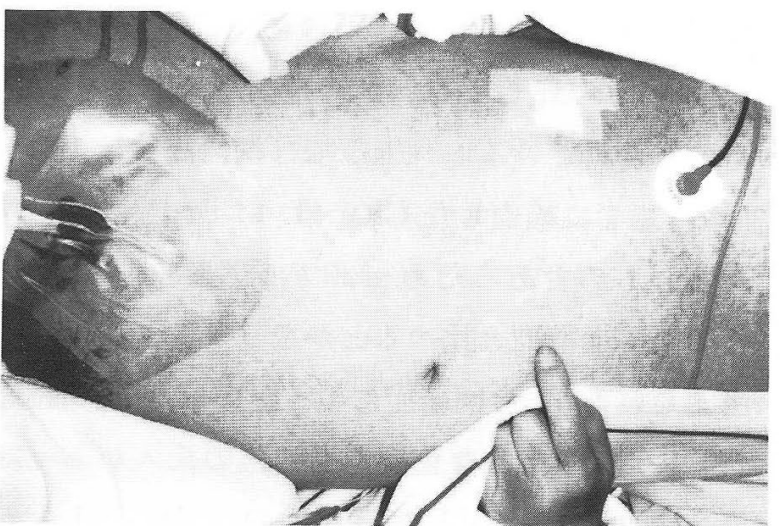

Fig. 1. Skin findings; macropapullar rash over the entire skin surface.

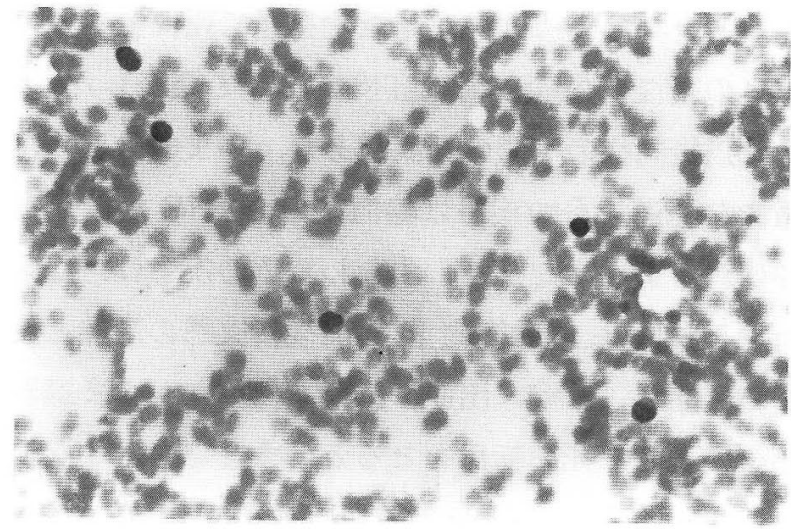

Fig. 3. Pathological findings in bone marrow.

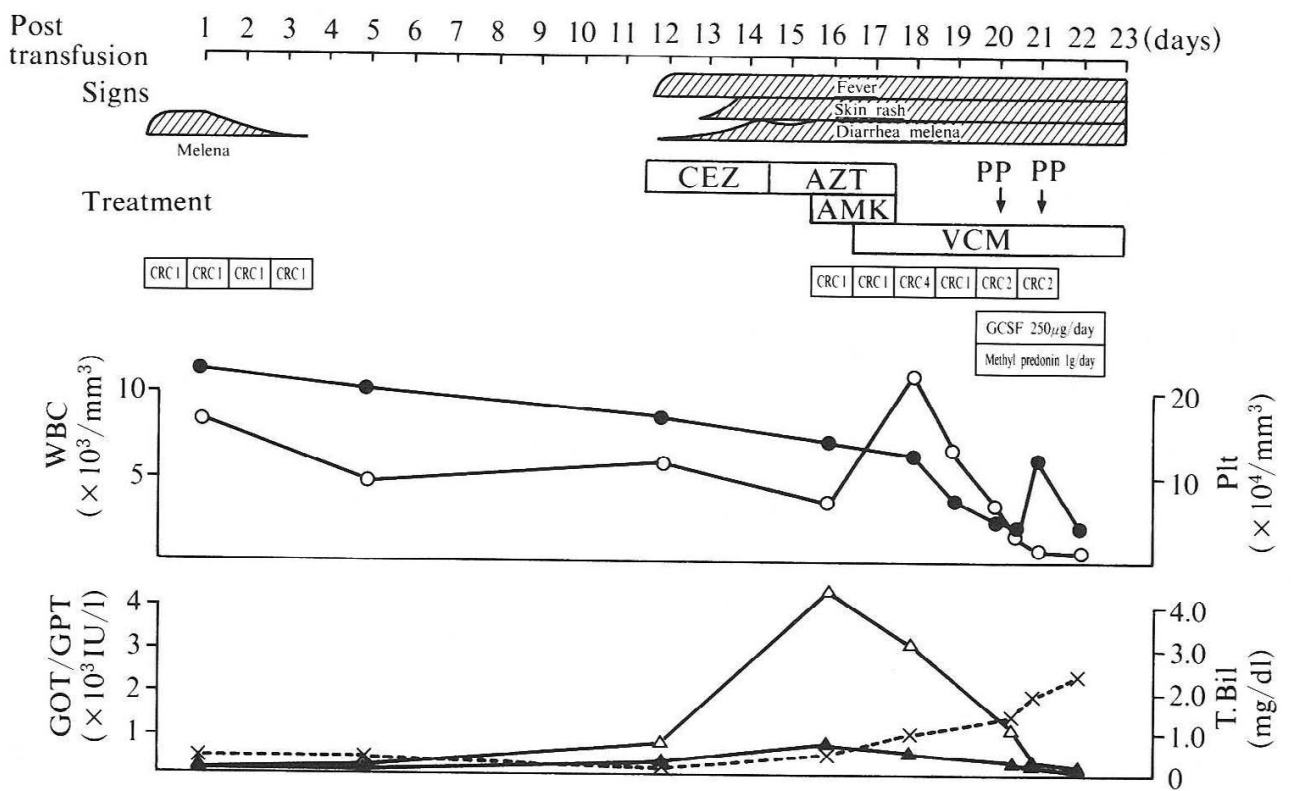

Fig. 2. Clinical course

$\mathrm{CEZ}=$ cefazolin ; $\mathrm{AZT}=$ azfreonam $; \mathrm{AMK}=$ amikacin $; \quad \mathrm{VCM}=$ vancomycin ;

$\mathrm{CRC}=$ condensed red blood cells ; $\mathrm{PP}=$ plasmapheresis $; \quad \mathrm{GCSF}=$ granulocyte colony stimulating factor

られ急速に悪化した点が特徴的であった（Fig. 2)。

尿培養で E. coli, 血液培養で St. epidermides を認 めた。髄液に異常所見はなかった。

凝固系検査では, 第 20 病日で PT 52\%, APTT 55.9 秒 (30.0), HPT 60\%, フィブリノーゲン $131 \mathrm{mg} / \mathrm{dl}$, アンチトロンビンIII 61\%であった。

第 20 病日に行った HLA タイピングにて, 患者本 来の A ローカス $(24 /-)$, B ローカス $(51 / 52), C$ ロ 一カス $($-/ー) が，それぞれ供血者の HLA 型と考
えられる24/一, 51/一, 一/一, または24/一, $52 /$, 一/一に移行していた。骨髄所見では, 著明な リンパ球の増殖，およびその他の骨髄細胞の消失 (aplastic crisis) がみられた（Fig. 3)。

皮膚抢よび肝生検所見では，炎症細胞の浸潤等の 所見が得られた。なお，剖検は施行していない。

\section{考察}

1955 年霜田は, 術後順調な経過をとりながら突然 
発熱・全身の発疹, 白血球減少を経て死に至る予後 不良の術後合併症を術後紅皮症として発表した1)。 それ以後同様の病態の発表があり，いまではその特 徵的な経過をもつ疾患は輸血後の GVHD 症候群と 呼ばれるようになった。すなわちその疾患は，臨床 所見としては,輸血後約 10 日前後に突然の高熱と皮 疹で発症し, 下痢・出血・感染を伴いながら多臓器 不全に至り，死の転帰をとるという経過を示す。検 査所見としては, $\mathrm{LDH} ・ \mathrm{GOT} ・ \mathrm{GPT}$ の上昇, 汎血 球減少症, 比較的軽度のビリルビンの上昇, 骨髄の 低形成とリンパ球の浸潤像，皮膚生検で炎症性細胞 の浸潤や基底層の液状変性, リンパ球 HLA 型の供 血者の型への変換, リンパ球キメラの証明を認める とされている2。

まず，われわれの症例を鑑別疾患の面から検討し てみる。この症例の特徵的な臨床経過と, 骨髄や皮 膚, 肝臓の病理所見は, 薬物アレルギーや中毒およ び感染症では説明が困難であり, リンパ球の HLA 型の変換の説明がつかないことより鑑別される。な お，本症例の皮膚所見では，基底層の液性変性はな いものの，正常ではあまりみられない基底層付近の リンパ球の浸潤が認められている。

1992 年の日本赤十字社の統計によると, 過去 5 年 間で GVHD と判定された症例は 171 例であり，う ち胸部血管外科が 67 例, 悪性腫瘍が 61 例であった。 男性 119 例，女性 45 例であった ${ }^{3)}$ 。

本症例で特徵的な点は, 日常診療や救急の場でご く普通に使われているCRCにて，GVHD が発症し た点である。これまでの文献 ${ }^{1-6)}$ では採血後 2 週間 以上経過した血液で発症しているのはまれであり, 女性では発症しにくいとされていた。本症例は，こ れらの 2 点でも特異的である。

つぎに，本症例が GVHD を起こした要因につい て考察してみる。host の状態, graft の免疫担当細胞 の量, host と graft の組織適合性との 3 点について 検討してみる。hostの状態としては 3 力月前の心 筋梗塞の既往があり，進行癌があった。GVHD の統 計でも開心術後や坦癌状態の患者に多くの GVHD
の発症が報告されている。つぎに graft のリンパ球 の量については, GVHD は $10^{7}$ 個以上流入すること が必要とされている4)。CRCでは採血直後は $10^{9}$ 存 在する。患者に輸血した CRC は，いずれも 2 週間以 上たったものであるため graft の細胞数は少なく, 通常の新鮮血輸血と比べるとかなりリスクが小さい と考えられたが, 今回発症に至ったのは, 2 週間経過 した CRCでも十分な免疫担当細胞の流入があった と考えられる。最後に組織適合性の点では, HLA の 型が近似していることが GVHD を発症しやすい要 因となっている ${ }^{4,6)}$ 。今回も供血者のものと考えられ る HLA 型と患者の HLA 型が A ローカスとC口 一カスで一致し, Bローカスと近似していた。この患 者が GVHD に至ったことは，心筋梗塞後で坦癌状 態という患者の状態, 十分な数のリンパ球の流入, 使用した CRC の組織適合性の近似等の諸条件の重 なりが少なからず寄与したと思われた。

治療については，発症するとすべての症例で死の 転帰をとり効果的な治療法がないのが現状である。 本症例でも抗生剤のほか, パルス療法, GCSF の投 与, 血漿交換等の治療を行ったが，結局無効であっ た。そのほかに試みられている治療法として，抗癌 剤, 抗胸腺細胞グロブリン等あるものの, ほぼ無効 とされている2,5,6)。

したがって，何にもまして予防が重要である。す なわち，できる限り輸血量を減らす（リンパ球の流 入を避ける), 移植片への放射線の照射, 積極的に自 己血輸血を導入することが考えられる。しかし，放 射線照射を行ってもGVHD が発症した報告例もあ る7)。また白血球除去フィルターも graft の数を減ら すことができるが十分ではない。CRC中の白血球 は, 採血直後は $10^{9}$ といわれているが約 3 週間で $10^{7}$ 以下に減少する（日本輸血学会誌第 36 巻 2 号)。最 近の MAP で処理した長期保存血が大勢を占めるよ うになれば， 3 週間を越えた保存血を使用すること でGVHD を減少させる可能性がある。

坦癌状態の患者や心筋梗塞後の患者が，原疾患あ るいは合併症による増悪で救急に来院し緊急の輸血 
が必要とする場合にしばしば遭遇する。このとき, GVHD を完全に避けることは困難と思われる。安易 な輸血をできるだけ避けるとともに，MAP 処理の 長期保存血を使用する等, 可能な限り GVHDを予 防することが重要と思われる。

\section{結 語}

1. 典型的な経過をとり, 受血者への HLA 型の変換 により確診し得た 67 歳女性の GVHDを経験した。 2. 本症例は女性である点, および 2 週間以上経過 した CRC 輸血での発症という点でまれな症例であ つた。

3. 救急の場において, 緊急の輸血は必要最少限に し，やむを得ず輸血するときは，GVHD も考慮に入 れる必要がある。

なお,この論文の要旨は第 20 回日本救急医学会総会 （1992 年，盛岡）にて発表した。

\section{文献}

1）霜田俊丸：術後紅皮症について。外科 $1955 ； 17$ ： 487-92.

2）伊藤和彦：輸血による GVHD．集中治療 1991 ； $3: 1329-34$.

3）十字猛夫：輸血後 GVHD 総合報告. 日本赤十字社 血液製剤の副作用の防止に関する研究班報告書. 1992, pp1-4.

4）井野隆史：輸血による GVH 反応の実態. 外科 $1987 ; 49: 875-83$.

5）井野隆史, 松浦昭雄, 高梨利一郎, 他：手術時の輸 血による GVHD 様症候群。外科 $1986 ; 48 ： 706-$ 12.

6）辛道秀樹, 浅野茂隆：輸血による GVHR とその対 策. Immunohaematology $1985 ; 7: 143-8$.

7) Starke ID, Thein SL : Graft-versus-host disease after treatment for chronic granulocyte leukaemia in transformation. Br J Haematol $1982 ; 52: 383-7$.

\section{DISCUSSION}

? 本症例の最も興味深い点は, 著者らも述べてい るように, 発症の危険性が少ないとされている 採血後 2 週間以上経過した血液の投与により GVHD
が発症したことである。このことは，全身状態のよく ない患者に輸血を行うことの多い救急の場での輸血の 意義と危険性を，私達はもっとクリティカルに考える 必要があることを示している。

しかし, 本症例では輸血後 GVHD として確定診断 できるかについては若干の疑問が残っている。輸血後 GVHD の確定診断には, 患者組織中に患者由来でない リンパ球を証明することが必要である。それは輸血前 後で患者の HLA が変化していること，あるいは患者 組織中に 2 種類のリンパ球の混在することにより示さ れる1)。本症例では HLA の変化を根拠としているよう であるが，論文中の記載が明確ではない。すなわち， 一般には輸血前には HLA 型の検索は行っておらず, 輸血後にその検索することもできないため，患者家族 の HLA より患者の HLA 型を推測し, 供血者の HLA と一致する本来患者にはないはずの HLA が輸血後に 認められることにより証明している。

本論文では A $(24 /-) ，$ B (51/52)，C (-/-) が患 者本来の HLA 型として記されているが，輸血前の型 をどのようにして決定したのかが不明確である。家族 の HLA より推定したのであれば，家族の HLA を含 めてその旨記載すべきであるし，そうでなければ，な ぜこの患者の HLA 型の判定を輸血前にあらかじめ行 っていたかを述べるべきであろう。また，供血者の HLA 型については「24/-,51/-,-/一または 24/一, 52/-,-/一と考えられる」と記載してあるが，実際に 供血者(4名)の HLA 検索を行ったのであろうか。わ が国は単一民族社会であるため，血縁のない他人と同 一のハプロタイプをもつ可能性は高い。しかし，C口

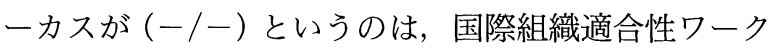
ショップで公認された $\mathrm{C}$ 抗原の型とは一致しないと いうことを表すのみであり，患者の C $(-/$ ) と供血 者のC (ー/ー) は必ずしも同一の型であったとは判定 できない。

考察では, 輸血 (CRC) 中の白血球数が約 3 週間で 100 分の 1 以下に減少するとの成績が引用されていた が，数のみならずその活性についても経日的に減少し てゆく。何をリンパ球活性の指標にとるかによって若 干の差はあるが, 採血後 2 週間でその活性は $30 \%$ 以下 になるという2)。大阪大学では採血後 1 週間以内の血 液に限り，放射線の照射が行われているが，本症例が GVHD であるとすれば, 照射対象を再考すべきであろ う。また，最近の第 4 世代の白血球除去フィルターは 99.99\%以上の除去率をもっているとされているので, GVHD の予防の観点から, 救急の場でこそ, 私達はフ 
イルターを使用すべきであろう。

最後に, MAP 処理により保存可能期間が延長 (採血 後 42 日) されたため, 採血後 3 週間以上経過した血液 を使用することは, GVHD の予防としては合理的であ ろう。しかし, 現在保存液として MAP を使用している のは, いわゆる濃厚赤血球液 (赤血球 $\mathrm{M} ・ \mathrm{~A} ・ \mathrm{P}$ 「日赤」) のみであり, 通常の保存血 (保存血液日赤 $\mathrm{CPD}\lceil$ 日赤」) には使用していないため, 考察での「3 週間を越えた保 存血」という記述は正確ではないことを指摘しておく。 また，最近では PCRにより，輸血後でも患者検体のみ でGVHDの確定診断が可能となっており，このよう な症例にはぜひ PCR を実施していただきたい。

\section{（大阪大学救急医学 吉岡 敏治）}

\section{文献}

1) 北村文近, 加藤禎洋, 日下部光彦, 他: HLA タイピ ングにより確診しえた大腸癌術後輸血後 GVHD の 1 例. 日臨外医会誌 $1994 ; 55: 61-5$.

2) 大軒子郎：全血中のリンパ球活性の経時的変化. GVHD の発症を予防するために；メディカルトピ ックス。医のあゆみ $1993 ; 17 ： 85$.

( ( (11 本症例が，輸血後 GVHD と確定診断された根拠の ひとつである，患者の HLA, A(24/-)，B(51/52)， C (-/-) が患者本人の型かどうかについて, 吉岡先生の ご指摘をいただきました。輸血前の本人の HLA 型は不明 で, 患者の家族の HLA 型の検索もできていません。そのた
め，本人のものどうかは，検查所見の分析よりの推定にと ぞまります。本来ならば, 経時的な検査を繰り返して HLA 型の変化をみていけば，より明らかになると思われます。 しかし, GVHD と強く疑った時点が遅く, 再度の検査時に は，HLA 型を検査するのに十分な白血球数がなく，初回の 検査のみとなりました。また供血者の HLA の検索も施行 し得ず(日赤の供給血), 先生のご指摘のように不十分な点 があったと思います。

今回, 輸血後 GVHD の診断に至るまで, 以下の疾患につ いて検討してみました。薬物アレルギーや中毒は，ひとつ ひとつの症候は起こり得てもすべての症候（皮疹，下痢， 出血, 感染, 肝障害, 腎障害, 多臟器不全) がそろうのは まれであり, 発症経過が合わない点および骨髄所見から本 症例の診断名とすることは困難でした。感染症も同様で, 活かに沉血球減少症を説明できない点から鑑別されまし た。DIC とは凝固系の異常に乏しい点や病理組織所見が合 わない点より鑑別されると考えました。以上のように，典 型的な臨床経過をもととして鑑別診断したところ, 臨床経 過, 検查所見, 病理学的所見の三者をすべて説明しうるの は GVHD しかなく，かつ，HLA の検査所見はそれを強く 支持するものとして本文の記載となりました。

最後に, CRC 中の白血球, MAP, GVHD の診断 (PCR) 等についても, 吉岡先生の貴重なご意見, ご指導をいただ き大変勉強になりました。この場を借りてお礼申し上げま す。

(橋本) 


\section{ABSTRACT \\ Graft Versus Host Disease (GVHD) Following Condensed Red Blood Cell Transfusion \\ Hiroshi Hashimoto', Kiyoshi Kaneko', Osamu Nakai1', Touki Nakamura' \\ Michihiko Masuda', Masaki Nakatou ${ }^{2}$ and Atsushi Sueyoshi ${ }^{2}$ \\ 'Department of Surgery, Uji Tokushukai Hospital \\ ${ }^{2}$ Department of Medicine, Uji Tokushukai Hospital}

A 67-year-old female was taken to the emergency room for anemia related to rectal carcinoma. Following condensed red blood cell (CRC) transfusion, she had a high fever and petechiae for 11 days. Diarrhea, melena and liver dysfunction were subsequently recognized, and she ultimately died of pancytopenia and multiple organ failure. Regarding the clinical course and HLA typing, a diagnosis of GVHD was made. Her immunological disorder was not particularly severe, and CRC had been made 14 days before. This kind of GVH reaction is very rare, but suggests that we should consider GVHD as a side effect CRC transfusion even in an emergency situation.

(JJAAM $1994 ; 5: 688-93$ )

Key Words : graft versus host disease (GVHD), condensed red blood cell, HLA typing, rectum cancer

Received for publication on December 13, 1993 (93-078) 